\title{
Cell-associated HIV RNA: a dynamic biomarker of viral persistence
}

\author{
Alexander O Pasternak*, Vladimir V Lukashov and Ben Berkhout
}

\begin{abstract}
In most HIV-infected individuals adherent to modern antiretroviral therapy (ART), plasma viremia stays undetectable by clinical assays and therefore, additional virological markers for monitoring and predicting therapy responses and for measuring the degree of HIV persistence in patients on ART should be identified. For the above purposes, quantitation of cell-associated HIV biomarkers could provide a useful alternative to measurements of viral RNA in plasma. This review concentrates on cell-associated (CA) HIV RNA with the emphasis on its use as a virological biomarker. We discuss the significance of CA HIV RNA as a prognostic marker of disease progression in untreated patients and as an indicator of residual virus replication and the size of the dynamic viral reservoir in ART-treated patients. Potential value of this biomarker for monitoring the response to ART and to novel HIV eradication therapies is highlighted.
\end{abstract}

Keywords: Cell-associated HIV RNA, Virological biomarker, HIV-1 persistence, HIV-1 reservoir, Antiretroviral therapy, HIV cure

\section{Review}

\section{Introduction}

The concentration of free virus particles in blood plasma (plasma viremia or plasma viral load), represented by the copy number of virion RNA per milliliter of plasma, which can be reliably quantified by PCR methods, is traditionally used as the biomarker of HIV-1 replication [1-3]. The main goal of antiretroviral therapy (ART) is suppression of plasma viremia to below the detection limit of the most sensitive assay available in the clinic, and maintaining this "undetectability". In most HIVinfected individuals treated with modern ART regimens and adherent to therapy, this goal is achieved and therefore, additional virological markers for monitoring the response to therapy should be identified. Ideally, such markers should be predictive of future ART complications (e.g. therapy failure due to suboptimal adherence) and should indicate the necessity of a clinical or behavioral intervention. In addition, recent efforts towards a functional or sterilizing HIV cure [4] have promoted a renewed interest in the development of quantitative and

\footnotetext{
* Correspondence: a.o.pasternak@amc.uva.nl

Department of Medical Microbiology, Laboratory of Experimental Virology, Center for Infection and Immunity Amsterdam (CINIMA), Academic Medical

Center, University of Amsterdam, Meibergdreef 15, 1105 AZ, Amsterdam, The Netherlands
}

(c) 2013 Pasternak et al.; licensee BioMed Central Ltd. This is an Open Access article distributed under the terms of the Creative Commons Attribution License (http://creativecommons.org/licenses/by/2.0), which permits unrestricted use, distribution, and reproduction in any medium, provided the original work is properly cited. the precise measurement of HIV reservoirs and aid in monitoring the effectiveness of the novel therapies aimed at eliminating or reducing these reservoirs [5-8].

It seems logical that, for the above purposes, quantitation of cell-associated (CA) HIV biomarkers could provide a useful alternative to the measurements of plasma viremia. Several viral nucleic acid forms, including different RNA (e.g. spliced, unspliced) and DNA (e.g. total, integrated, unintegrated) molecules, are present in the infected cell at different points of the lentiviral replication cycle (Figure 1). Because these molecules represent HIV reservoirs with different properties, each of these molecules can, in principle, be utilized as an HIV biomarker using sensitive PCR-based techniques. However, with the exception of an assay for total CA HIV DNA, used for HIV diagnostics in infants [9], no quantitative assay for a CA HIV marker is currently in the clinical practice, despite a large body of research on the topic. Several recent reviews focused on the different molecular forms of CA HIV DNA, such as integrated and unintegrated DNA forms $[10,11]$. This review concentrates on the CA HIV RNA with an emphasis on its use as a virological biomarker. 


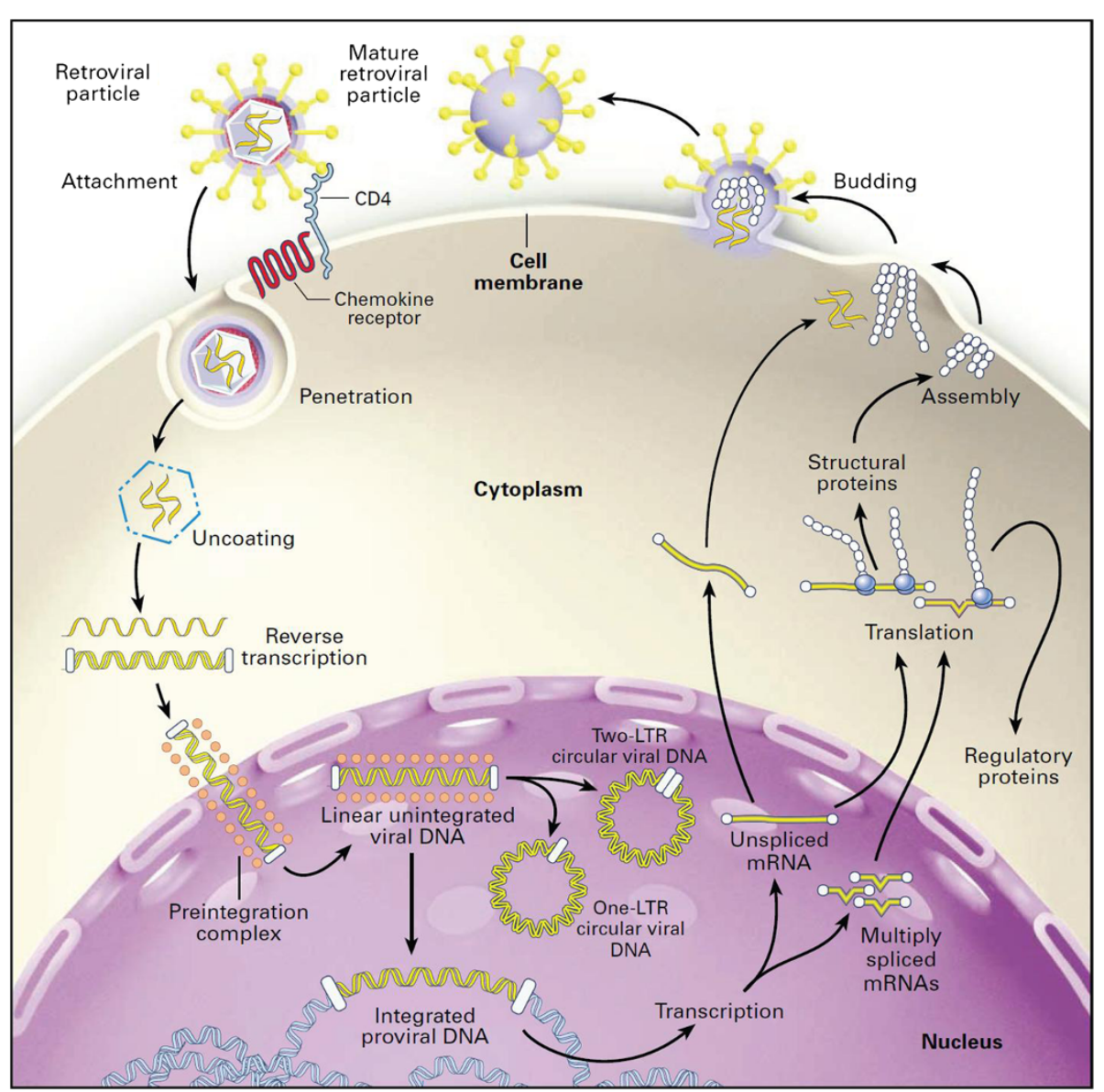

Figure 1 The essential steps in the life cycle of HIV-1. The first step is the attachment of the virus particle to receptors on the cell surface. The HIV-1 RNA genome then enters the cytoplasm as part of a nucleoprotein complex. The viral RNA genome is reverse-transcribed into a DNA duplex, which has terminal duplications known as long terminal repeats (LTRs). The linear viral DNA molecule is part of the preintegration complex that enters the nucleus. In the nucleus, unintegrated viral DNA is found in both linear and circular forms. The unintegrated circular forms of viral DNA have either one or two LTRs, are byproducts of the integration process, and are found exclusively in the nucleus. The linear unintegrated viral DNA is the precursor of integrated proviral DNA, which is a stable structure that remains indefinitely in the host-cell genome and serves as a template for viral transcription. Transcription of the proviral DNA template and alternative RNA splicing creates spliced viral RNA species encoding the viral accessory proteins, including Tat, Rev, and Nef, and the unspliced viral RNA encoding the viral structural proteins, including the Gag-Pol precursor protein. All the viral transcripts are exported into the cytoplasm, where translation and assembly and processing of the retroviral particle take place. The cycle is completed by the release of infectious retroviral particles from the cell. (Figure adapted from [12]; reproduced, with permission, from Massachusetts Medical Society @ 1999 ).

\section{CA HIV RNA in the viral replication cycle}

More than 40 different viral RNAs are produced in HIVinfected cells by alternative splicing of the primary transcript, which is transcribed from the integrated provirus (Figure 2A) [13,14]. Initially, only short ( 2 kb) completely spliced, also termed multiply spliced $(\mathrm{ms})$, transcripts are produced, encoding the regulatory proteins Tat, Rev, and Nef. As the infection progresses, there is a shift towards production of $\sim 9 \mathrm{~kb}$ unspliced (us) and $\sim 4$ $\mathrm{kb}$ incompletely spliced (is) transcripts, encoding the structural and accessory proteins Gag, Pol, Env, Vif, Vpr, and Vpu [15-17]. This shift is dependent on the threshold level of the Rev protein, which facilitates the export of the usRNA and isRNA molecules from the nucleus by binding to the RRE (Rev-responsive element), an elongated stem-loop structure located in the Env open reading frame [18,19] (Figure 2B). In addition to its use as a template for translation of the Gag protein and the Gag-Pol polyprotein, usRNA is packaged into progeny viruses as genomic RNA.

\section{CA HIV RNA in untreated patients}

During the 1990s, several groups reported detection and quantitation of CA (us and ms) HIV-1 RNA in peripheral blood cells [22-30] and tissues [31-35] of infected individuals. In these initial studies, qualitative, semiquantitative, or quantitative competitive (QC) reverse transcription (RT)-PCR methods, as well as in situ 


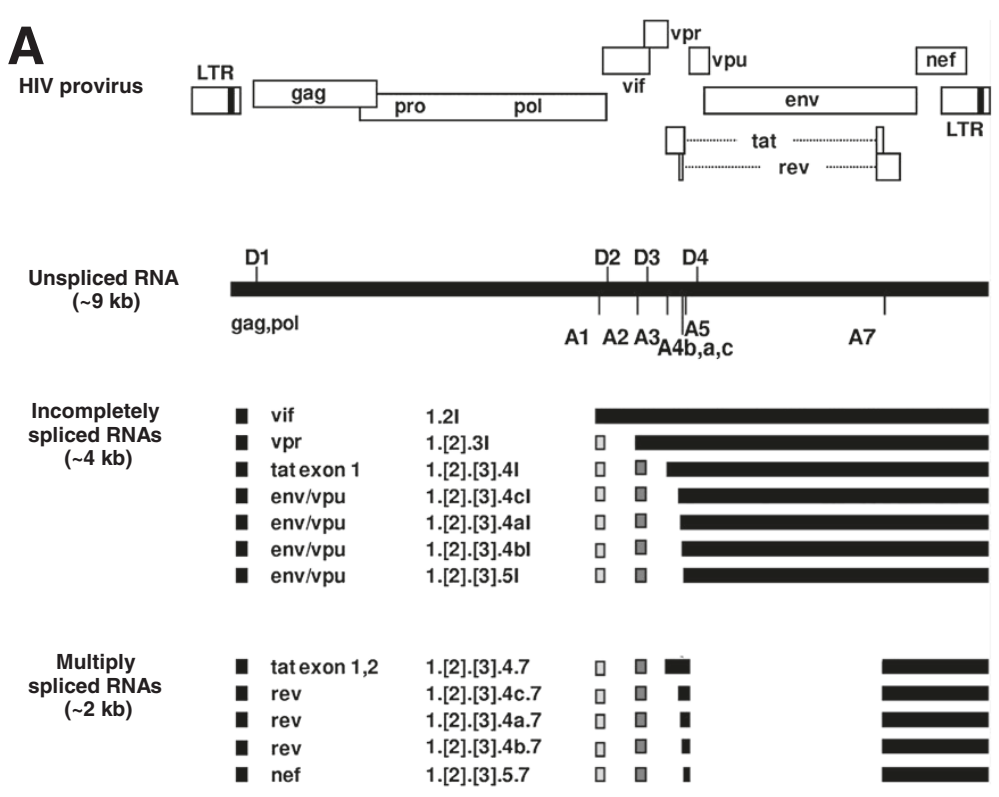

B

Early Phase (no/low Rev)
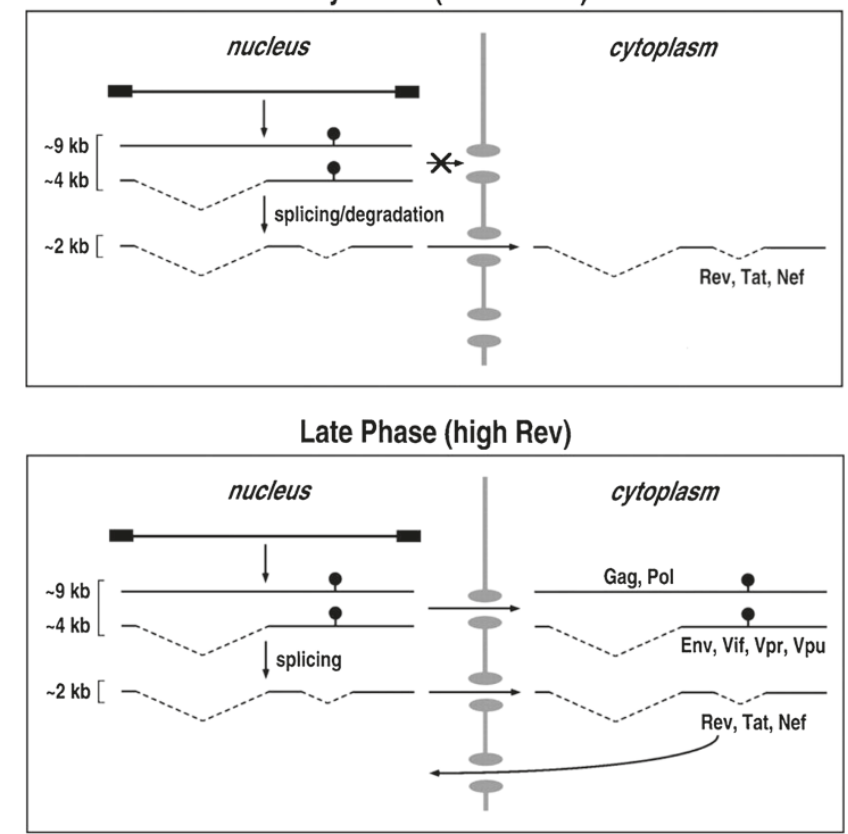

Figure 2 Viral RNA species produced within HIV-1-infected cells and phases of HIV-1 RNA expression. (A) Viral RNA species produced within HIV-1-infected cells. HIV-1 genes are shown relative to the long terminal repeats (LTR). The viral genomic or 9-kb unspliced RNA shows the location of $5^{\prime}$ (D) and $3^{\prime}$ (A) splice sites. The incompletely and multiply spliced HIV-1 viral RNAs (4-kb and 2-kb size classes) are shown as black boxes. Spliced RNAs are denoted by the translated open reading frames and by the exon content. (Figure is adapted from [20]; reproduced, with permission, from American Society for Microbiology () 2008.) (B) Early and late phases of HIV-1 RNA expression. Full-length unspliced 9-kb RNA, incompletely spliced 4-kb RNA, and multiply spliced 2-kb RNA species are constitutively expressed in the nucleus. In the absence of Rev (upper panel), or when the concentration of Rev is below the threshold necessary for function, the 9-kb and 4-kb transcripts are excluded from the cytoplasm and either spliced or degraded. In contrast, the fully processed 2-kb RNA are constitutively exported to the cytoplasm and used to express Rev, Tat, and Nef. When the levels of Rev in the nucleus are sufficiently high (lower panel), the nuclear export of 9-kb and 4-kb RNAs is activated and the translation of all viral proteins ensues. (Ball and stick) The Rev response element. (Figure adapted from [21]; reproduced, with permission, from Annual Review of Microbiology ( 1998). 
hybridization-based methods, were used. Before the introduction of combination ART (1996-1997), the main focus of these studies was to verify whether CA HIV RNA could be used as a virological biomarker of disease progression in untreated individuals. Almost 20 years ago, by comparing CA HIV burden (DNA and RNA) between lymphoid tissue mononuclear cells and peripheral blood mononuclear cells (PBMC), it was convincingly demonstrated that during the asymptomatic phase of infection ("clinical latency") most HIV replication occurs in lymphoid tissues [33]. Nevertheless, a single measurement of HIV-1 msRNA in PBMC in the asymptomatic phase was strongly associated with progression to AIDS in a cohort of 150 homosexual men [36], showing that HIV replication is adequately represented in peripheral blood. Similar predictive power for disease progression was demonstrated for plasma viremia $[37,38]$. However, time trends of plasma viremia in the asymptomatic phase were found to be highly variable between patients and between studies: a steady-state pattern is usually observed [39], but a U-shaped curve [40] or a gradual increase over time [41] have also been reported. In contrast, CA HIV RNA level in typical progressors was demonstrated by several studies to significantly increase during this phase of infection and to inversely correlate with the $\mathrm{CD}_{4}^{+} \mathrm{T}$ cell count $[23,28,42-44]$. Slow progressors, in comparison, typically have lower and relatively constant CA RNA levels $[28,42,43,45,46]$.

We performed a direct comparison of the longitudinal trends of viral RNA in PBMC and plasma (CA HIV RNA in this study was measured by seminested realtime PCR) in a cohort of HIV-infected untreated individuals with a mean follow-up of 55 months [44]. This comparison revealed remarkable differences in the dynamics of these molecular markers. While levels of viral RNA in plasma were stable, those of CA usRNA in PBMC were significantly increasing over time, and levels of usRNA, but not plasma viremia, inversely correlated with the $\mathrm{CD}^{+} \mathrm{T}$ cell count. Interestingly, levels of usRNA increased in time significantly faster than those of CA HIV DNA, with a concominant increase of the RNA/DNA ratio [44]. Whether this increase of viral RNA expression in PBMC reflects an increase in the relative numbers of HIV-producing cells per HIV $\mathrm{DNA}^{+}$ cell as the infection progresses, or an upregulation of viral transcription in PBMC at the cellular level, remains unclear. Previously, by quantitative microculture assay, Gupta et al. [28] demonstrated that the relative number of HIV-producing cells in untreated individuals parallels the level of usRNA and inversely correlates with the $\mathrm{CD}^{+}{ }^{+}$counts. Progressive weakening of the antiviral immune response during the asymptomatic phase might be one of the factors defining the temporal increase in the relative numbers of HIV-producing cells and therefore the increase in HIV-1 replication rates in PBMC that we and others have described.

Another interesting (and controversial) issue is whether the relative dynamics of usRNA and msRNA in infected individuals is predictive of disease progression. Most viral RNA expressed early by the infected cell is multiply spliced, with unspliced and incompletely spliced RNA forms "taking over" later. Thus, the us/ms RNA ratio in cells from infected individuals can be used as a surrogate marker of the relative numbers of infected cells in the early vs. late stages of virus replication. Several groups $[24,42,46]$, but not all $[43,45]$, reported an increase of the us/ms RNA ratio in PBMC from HIV-infected persons as the infection progresses, and a preponderance of msRNA was demonstrated in long-term nonprogressors compared with typical progressors [47]. In our cohort, a nonsignificant trend towards a longitudinal increase of the us/ms RNA ratio in typical progressors was observed [44].

To explain this phenomenon, the concept of "blocked early-stage latency" has been put forward, by analogy to certain latently infected cell lines (U1, ACH-2) that also demonstrate a preponderance of msRNA production when unstimulated $[48,49]$. The existence of a significant reservoir of such latently infected cells during the asymptomatic phase of infection in infected individuals was proposed [24]. Alternatively, the difference in the us/ ms RNA ratio could be explained by temporal changes in the cytotoxic $\mathrm{T}$ lymphocyte (CTL) response. Progressive weakening of the CTL response as the infection progresses would mean that cells in the late, productive phase of infection (which is characterized by an excess of usRNA and isRNA species) are killed at a reduced rate so that more and more cells with an excess of usRNA are present [50]. In agreement with this idea, rapid progression was shown to be associated both with weaker CTL responses and higher us/ms RNA ratios [51].

\section{CA HIV RNA in ART-treated patients Assays to quantify CA RNA in patients on ART}

Already in the early days of combination ART, numerous papers reported detection and quantitation of CA HIV RNA in peripheral blood and tissues of patients on suppressive therapy [12,52-63]. The advent of combination ART roughly coincided with the introduction of realtime PCR methods for nucleic acid quantitation. As a result, most of the developed quantitative assays for CA HIV RNA and DNA in patients on ART are based on real-time PCR [58,64-68]. These assays are highly specific, but to be able to measure minute amounts of HIV nucleic acids in limited biological material from patients on suppressive ART, the assay sensitivity had to be boosted. We achieved this by addition of a limited-cycle (in order to stay in the linear range) preamplification step with seminested primers before the real-time PCR, 
resulting in a dramatic improvement of assay sensitivity without compromising the linearity of the standard curve [69]. As a result, this seminested real-time PCR assay allows routine detection and quantitation of HIV RNA and DNA in the vast majority of PBMC samples of patients on combination ART with undetectable plasma viremia $[69,70]$. Notably, this technology results in a dramatic reduction of the necessary amount of input biological material. Other groups have adapted the commercial quantitative tests for HIV-1 plasma viremia (e.g. Roche Amplicor) for the quantitation of CA HIV RNA [55,71,72]. Detection/quantitation of CA HIV RNA in patients on ART by the in situ hybridization-based assays $[61,73]$, as well as by transcription-mediated amplification (TMA) [74] have also been reported.

In any assay, the quantified amount of CA HIV RNA needs to be normalized to the cellular input. However, simple cell counting or total RNA measurement in the sample is insufficient, as differences in efficiencies of both RNA isolation and reverse transcription between different samples also need to be taken into account. We routinely determine the cellular inputs of our cDNA samples by quantifying $18 \mathrm{~S}$ ribosomal RNA in a separate realtime PCR [69,70]. Housekeeping genes (e.g. GAPDH) have also been used for this purpose [66], but there is evidence that $18 \mathrm{~S}$ ribosomal RNA may be a better choice for normalizing real-time PCR data, especially for virus-infected cells [75]. If one is working with total PBMC, it also makes sense to normalize the CA HIV RNA signal to the percentage of $\mathrm{CD}_{4}^{+} \mathrm{T}$ cells in the sample. The latter can be determined either directly by flow cytometry or approximated by the $\mathrm{CD} 4^{+}$cell count per microliter of blood (which is usually available), as a strong positive correlation is commonly present between $\mathrm{CD}_{4}^{+}$counts and $\mathrm{CD} 4^{+}$ percentages [76].

One well-known problem that relates to all hybridizationbased methods of HIV nucleic acid quantitation is the extreme heterogeneity of HIV sequences, in particular when different virus subtypes are encountered. For real-time PCR methods, this translates into possible effects of mismatches between the primer or probe with their binding sites on the efficiency of real-time PCR, as presence of even a single mismatch may reduce the PCR efficiency by several logs [77-81]. This complicates the analysis, especially when comparing samples of different patients. Using degenerate primers [82] and targeting conserved regions of the HIV genome, like gag, pol, or LTR sequences [83,84], helps to reduce this problem to some extent. Interestingly, two more radical solutions have also been described. One solution is to use patient-matched PCR primers (and probes) for the real-time PCR $[67,85]$. However, this approach can become quite laborious and expensive if samples from a large number of patients are being studied, as not only the primers and probes, but also the quantitation standards have to be patient-matched and tested. Another shortcoming of this approach is that the matching is done to only one (or possibly several, if degenerate primers are used) predominant viral sequence(s), with the risk of misrepresentation of all minority HIV-1 variants.

We proposed another radical solution: to calculate, for each patient, individual mismatch-related quantification errors (MRQE) and normalize all quantified amounts of HIV RNA (or DNA) to the MRQE values [70]. The $M R Q E$ values are produced by performing a real-time PCR in which the patient-derived PCR amplicons, containing the primer and probe target sites, are used as templates. The concentrations of the template amplicons are determined spectrophotometrically and equalized by dilution before real-time PCR. A control template without mismatches is amplified as well. Patient-specific MRQE are calculated as the differences between the $\log _{10}$-transformed output copy numbers of the individual patient-derived templates and the control template.

\section{Decay kinetics of cell-free and CA HIV RNA upon ART initiation}

Initiation of combination ART causes a rapid decline in plasma viremia, which occurs in several phases, and almost invariably leads to a level that is undetectable by current commercial assays (20-50 copies/ml). However, by sensitive assays [86-91], low levels of free virus can still be detected in a majority of patients on ART [92]. After several years of therapy, this residual viremia reaches a plateau of $1-10$ copies $/ \mathrm{ml}$ and does not appear to decline any further [93]. The total drop in plasma viremia on ART, depending on pre-therapy values, is thus $3-6 \log _{10}$. Remarkably, CA HIV RNA in PBMC and lymph nodes follows similar decay kinetics upon ART initiation, with a rapid initial decline towards a plateau, but the drop is only $1-2 \log _{10}$, as shown by several groups (Figure 3) [12,59,70,94-98]. Plasma viremia

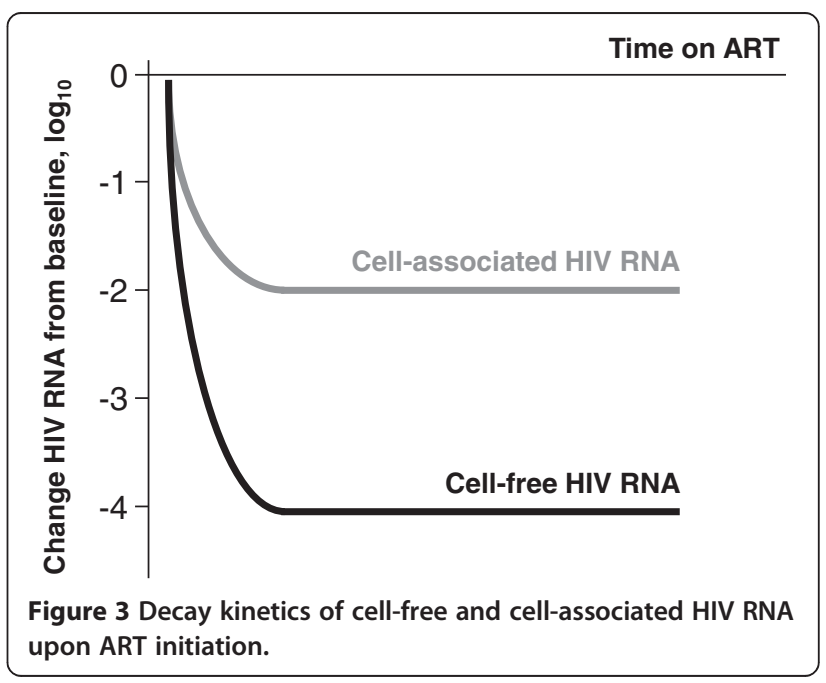


reflects a balance between virus production and virus clearance, and because clearance of free virus in HIV infection was shown to be very rapid, with a half-life in the order of minutes to hours $[99,100]$, plasma viremia is considered to be directly proportional to virus production. Likewise, the viral decay kinetics in plasma upon ART initiation is considered to mimic the decay kinetics of HIV-producing cells [2,101]. In a productively infected cell population, the CA HIV RNA load is also considered to be proportional to virus production. Therefore, in view of classical models of viral dynamics [102], the observed disproportion between the cell-free and CA viral RNA in untreated patients and patients on ART remains puzzling.

To explain this discrepancy, one may assume the existence of a subpopulation of cells that contain viral RNA but either do not produce detectable virus at all, or produce only minute amounts of viral particles. One possibility is that these are latently infected cells that do not produce virus particles due to either insufficient viral RNA transcription, nuclear retention of usRNA or msRNA, or both $[64,103]$. Obviously, as ART only stops infection of new cells but does not prevent viral RNA transcription, these cells are not expected to decay upon ART initiation and are responsible for the "background level" of CA RNA in patients on ART. Alternatively, this "background level" of CA RNA without a corresponding level of free virus in plasma may reflect residual HIV replication occurring by cell-to-cell transfer, as no detectable free virus is produced during this process (see below).

Another possible explanation for the observed disproportion between the cell-free and CA viral RNA at high and low viral loads is that virion clearance may not be a simple first-order reaction and its rate may be inversely proportional to the viral load, as shown for hepatitis B virus [104]. Interestingly, the clearance rate of SIV in experimentally infused naïve monkeys or infected monkeys with low viral loads was demonstrated to be $\sim 10$-fold higher than the HIV clearance rate in untreated chronically infected patients as measured by plasma apheresis $[100,105]$. Notably, in the latter study, the longest halflife of free virus was measured in the patient whose viral load was $\sim 1 \log _{10}$ higher compared to other patients [100]. In rhesus macaques, neutralizing antibodies (Nab) were shown to accelerate clearance of free virions [106]. The Nab-mediated clearance rate may be saturated at high viral load and especially efficient at low viral load, in particular because HIV-specific Nab titers decline by only $\sim 1 \log _{10}$ on ART, much less than does free virus $[107,108]$, and therefore, more Nab per viral particle would be available at low viral loads. Therefore, virion clearance may be extremely rapid in patients on ART and consequently, less free virus particles may be detected per virus-producing cell in these patients than in untreated patients with high viral loads.

\section{Cellular origin of CA HIV RNA in patients on ART}

A number of important insights into the persistence of CA HIV RNA in patients on ART have been obtained from the work of Fischer and colleagues [59,67,85,109-112]. In particular, by freeze-thaw nuclease digestion prior to RNA isolation and RT-PCR, they could differentiate between genuine intracellular HIV-1 usRNA and extracellular virion RNA attached to a cell, and demonstrated that the latter represents $\sim 12 \%$ of total PBMC-associated usRNA in untreated individuals but only $<0,5 \%$ in patients on suppressive ART [109]. This means that $>99,5 \%$ of CA usRNA in patients on ART represents intracellular transcripts. The cellular origin of these transcripts is an important issue in HIV persistence under therapy: these transcripts may originate either (i) from latently infected cells (latency is defined here as lack of virion production), (ii) from cells reactivated from latency to undergo productive infection with virion release but without infection of new cells, or (iii) from cells newly infected despite ART.

Latently infected resting memory $\mathrm{CD}^{+} \mathrm{T}$ cells are considered a major HIV reservoir in patients on ART and a main barrier to virus eradication, due to the relative stability of this cell population [113]. By isolating extremely pure populations of resting $\mathrm{CD}^{+}{ }^{+} \mathrm{T}$ cells from patients on ART, Siliciano's group demonstrated very low copy numbers of full-length usRNA and msRNA in these cells ( $<10$ copies $/ 10^{6}$ cells $)$ and an excess of short abortive transcripts that terminate prior to nucleotide $181[114,115]$. In addition, msRNA in resting $\mathrm{CD}^{+} \mathrm{T}$ cells from patients on ART was shown to be retained in the nucleus, precluding translation of viral Tat and Rev proteins and consequently high-level transcription and nuclear export of usRNA and isRNA [103]. These effects likely contribute to the latent state of HIV in these cells. Interestingly, the same pattern of nuclear localization of msRNA was recently observed in a chemokine (CCL19) induced model of HIV latency in primary resting $\mathrm{CD}^{+}$ $\mathrm{T}$ cells [116]. In vivo, a resting memory $\mathrm{CD}^{+} \mathrm{T}$ cell can undergo reactivation as a response to antigens or cytokine induction. If this cell is latently infected with HIV, reactivation may trigger the transition to productive infection [117]. In accordance with this, ex vivo and in vitro stimulation of resting $\mathrm{CD}^{+} \mathrm{T}$ cells resulted in relocalization of HIV msRNA to the cytoplasm [103,116].

By PBMC fractionation coupled to limited dilution analysis (LDA) and real-time PCR, Fischer's group has demonstrated significantly higher per-cell CA HIV RNA load in activated than in resting $\mathrm{HIV} \mathrm{RNA}^{+} \mathrm{CD}^{+}{ }^{+}$cells from patients on ART [67]. However, very few cells among the total bulk of $\mathrm{HIV} \mathrm{DNA}^{+}$resting cells can be reactivated to productive infection [114], and it therefore remains unclear whether latently or productively infected $\mathrm{CD}^{+}{ }^{+} \mathrm{T}$ cells are responsible for the largest fraction of CA HIV RNA in patients on ART. Fischer et al. 
have further shown that $>90 \%$ of all PBMC-associated HIV RNA in patients on ART is derived from cells that contain low to intermediate amounts of usRNA and low or undetectable amounts of msRNA [112], suggesting that a substantial fraction of these cells is latently infected. A similar conclusion can be drawn from the analysis, by the same authors, of CA HIV RNA in lymphoid tissues of patients on ART [111]. These results seem to contradict the earlier work of Hockett et al. that estimated, using in situ hybridization (ISH) and quantitative PCR methods, that the vast majority of CA HIV RNA in lymphoid tissue of patients on suppressive ART is contained within a few cells with an RNA copy number per cell similar to that in untreated patients $\left(>3 \log _{10}\right.$ copies/cell) [57], suggesting that these cells are productively infected. This apparent contradiction can be attributed to relatively low sensitivity of the ISH method used by Hockett et al., which could have hampered the detection of cells harboring low levels of HIV RNA. Importantly, due to the low patient numbers in both studies, the studies could have selected patients belonging to different populations, e.g. with respect to the CTL responses (see below).

\section{CA HIV RNA as a marker of the "active viral reservoir"}

The vast majority of cells harboring HIV provirus do not transcribe any viral RNA, both in untreated and ARTtreated patients [112]. Some of these cells are able to support productive HIV infection upon reactivation, but unless such cell is reactivated to productive infection, it stays invisible to the immune system as it does not produce any viral antigens. Total CA HIV DNA is therefore a biomarker of the total proviral reservoir, comprised of cells that do or do not transcribe viral RNA. CA HIV RNA, on the other hand, is a biomarker of a subset of the total viral reservoir, containing cells in which HIV sequences are actively transcribed ("active HIV reservoir"). This "active reservoir" should not be seen as a "frozen" population of infected cells with distinct properties, but rather as a "snapshot" of a dynamic system at a particular point in time. As discussed above, a subset of this "active reservoir" may consist of cells in which viral proteins are not produced due to insufficient transcription levels and/or mislocalization of viral RNA. However, a recent report demonstrated that resting $\mathrm{CD}^{+} \mathrm{T}$ cells are capable of producing Gag protein without spreading infection in an in vitro latency model [118], suggesting another level of HIV latency regulation. If most of the resting $\mathrm{CD}^{+}{ }^{+} \mathrm{T}$ cells that transcribe some viral RNA can produce some viral proteins, it means that the "active viral reservoir", for a large part, consists of cells that present antigenic stimulation to the host immune system. In line with this, the presence of CA HIV RNA in patients on ART was shown to directly correlate with lymphoproliferative responses to the HIV-1 p24 antigen [61].

Interestingly, a recent study on elite and "secondary" controllers (patients who control viremia at $<50$ copies/ $\mathrm{ml}$ either without treatment or after treatment discontinuation, respectively) also indirectly confirms this notion, as both patient groups had significantly lower usRNA levels as compared to patients on ART with plasma viremia suppressed to $<50$ copies/ml [119]. In addition, both elite and secondary controllers showed higher T-cell proliferative responses to Gag and Pol peptides [119]. This suggests that natural HIV control, as opposed to the ART-mediated control, may be exerted mainly through host CTL responses that eliminate cells expressing viral antigens ("active HIV reservoir"), possibly explaining why this reservoir in natural controllers was very limited. This is supported by a recent study that found that elite controllers harbor lower levels of integrated HIV DNA than patients on ART, despite comparable levels of total DNA [120]. As transcription/ translation from HIV integrated DNA is much more efficient than from unintegrated DNA [11], cells harboring integrated viral DNA and transcribing viral RNA could be preferentially destroyed by the CTL response. Interestingly, the size of the "activatable" HIV reservoir, estimated by the infectious unit per million (IUPM) assay (this assay measures the frequency of infected cells capable of producing virus upon ex vivo stimulation), was also shown to be at least $1 \log _{10}$ lower in natural controllers than in patients on ART [121]. In another report, patients who initiated ART early (3-15 weeks after infection) were shown to have up to $2 \log _{10}$ lower usRNA levels and $1 \log _{10}$ lower viral transcription rates (HIV RNA/DNA ratios) under ART than patients that started therapy during chronic infection [85]. This extends the findings of Strain et al. that the replication competent viral reservoir is significantly smaller in subjects starting ART early in infection [122]. Early ART is thought to preserve immune functions and limit the possibilities for HIV to escape from host immunity, likely explaining why a significantly larger fraction of the "active reservoir" was eliminated in patients starting therapy early.

Therefore, in patients on ART, it is plausible that continuous transcription of CA viral RNA and expression of HIV antigens on the surface of infected cells, even in the absence of virion production and/or infection of new cells, would exert continuous pressure on the immune system and cause additional morbidity as a result of persistent immune activation, inflammation, and immunosenescence [123]. Despite the fact that ART has dramatically increased the median survival time of HIV-infected individuals, several studies have found excess mortality rates in the infected and ART-treated population compared to the general population [124-126]. It is unclear whether this 
excess mortality is due to the effects of HIV infection itself, the adverse effects of the antiretroviral drugs, or to any possible co-infections and co-morbidities. If the former is true, it is necessary to develop quantitative virological biomarkers to monitor these effects. Further studies are warranted to establish whether CA HIV-1 RNA can be used as a reliable surrogate marker of such effects, but several reports already point to a direct correlation of CA HIV RNA levels with markers of immune activation in untreated patients, natural controllers, and patients on ART [127-129].

\section{CA HIV RNA as a marker of residual virus replication}

Since the introduction of potent ART, it has been unclear whether low-level HIV replication is occurring in (some) patients on ART, and a considerable debate on this matter has been ongoing for some time [7,117,130-135]. Obviously, understanding whether viral reservoirs in patients on ART can be replenished by residual HIV replication is important for designing possible therapeutic interventions (e.g. therapy intensification to abolish the residual replication). In addition, because long-lived latent HIV reservoirs pose a major obstacle to an HIV cure, a number of strategies to eliminate latently infected cells by induction of virus production are currently being tested [5-7]. Notably, complete inhibition of HIV replication seems an absolute prerequisite for any such strategy to work, because if infection of new cells is not completely inhibited, such a strategy may result in further dissemination of the HIV reservoir, instead of virus eradication $[4,136]$.

Direct demonstration of infection of new cells in a patient on ART is, however, extremely difficult, and therefore, a number of studies have attempted to show residual HIV replication by demonstrating virus evolution in patients on ART. However, these studies could not detect virus evolution or emerging drug-resistance mutations in the majority of patients $[132,134,135,137-139]$. Very recently, data have been reported that suggest that even if some virus evolution is detected in a patient on ART, the evolutionary rate is very low [140]. This lack of significant virus evolution in patients on ART is currently seen as one of the strongest points against residual HIV replication.

Attempts have also been made to demonstrate HIV replication despite therapy by studying levels and longitudinal trends of virological biomarkers. In particular, since the first reports describing persistence of CA HIV RNA in patients on ART, it has been proposed as a possible biomarker of residual virus replication [53,56,58,61]. However, it soon became clear that the mere presence of viral RNA in infected cells does not at all imply virus replication, as CA HIV RNA can be derived from cells reactivated from latency and even from latently infected cells. This is likely true for all CA HIV RNA species, including msRNA.
MsRNA production, relative to that of other viral RNA species, is elevated at the early stages of HIV life cycle, and most msRNA in untreated individuals is thought to be derived from newly infected cells [141]. In accordance with this, the decay of msRNA upon ART initiation is much faster than that of usRNA $[66,85,94,141]$, and most studies have reported lower detectability and levels of msRNA compared to usRNA in patients on suppressive ART $[67,70,109,111]$. Still, the presence of msRNA in patients on ART does not per se signify a recent infection, or even a productive infection. A temporal shift towards a higher msRNA/usRNA ratio in a patient on ART could, however, suggest some new infection events, and therefore, the relative abundance of different CA HIV-1 RNA species is a potentially informative biomarker of residual replication in patients on ART. Such cases have not yet been described, probably due to the extremely low msRNA levels in patients on ART.

UsRNA is more abundant and therefore more easily detected, and several studies could link its expression to the residual virus replication. Two studies that followed patients from the start of ART have reported a reverse correlation between HIV usRNA levels and decay rates of CA HIV DNA on therapy, suggesting that the viral reservoir may have been replenished by ongoing residual replication [66,97]. Some (but not all) groups have measured a substantial reservoir of CA HIV RNA and DNA in monocytes from patients on ART [63,67,142]. As monocytes only circulate in peripheral blood for 1 to 3 days before entering tissues and differentiating into macrophages, the mere presence of HIV infection in these cells was interpreted as evidence for recent infection and residual replication under ART [63].

Another approach to demonstrate residual virus replication under therapy is to show a change in level of a virological biomarker upon an increase (e.g. therapy intensification) or a decrease (e.g. suboptimal adherence) in therapy pressure. A recent study that used such an approach reported a decrease in the level of HIV-1 usRNA in the ileum upon therapy intensification with raltegravir (an integrase inhibitor) [143], suggesting that residual replication may be ongoing in some compartments. Alternatively, residual virus replication can be demonstrated by showing a link between an expression level of a virological biomarker and a certain clinical endpoint. Using this approach, we have demonstrated, by seminested real-time PCR, that higher levels of HIV-1 usRNA in PBMC are predictive of future therapy failure in patients on ART with undetectable plasma viremia [70]. The predictive value of usRNA for virological response to ART was recently confirmed by an independent study that used a completely different RNA detection assay, namely simultaneous ultrasensitive subpopulation staining/ hybridization in situ (SUSHI) [144]. 
These observations suggest that residual viral replication continues on ART in some patients, leading to the development of drug-resistance mutations and, as a consequence, therapy failure. However, most patients treated with modern ART do not demonstrate therapy failure. Therefore, as a next step, we studied the influence of decreased ART pressure (as a result of modestly decreased adherence to therapy) on the levels of cell-associated virological markers in patients on ART with long-term virological success. Surprisingly, we observed that even modest deviations from perfect adherence to ART (electronically measured adherence never fell below 70\% in any patient), caused a significant longitudinal increase in the levels of usRNA, but no virological rebound in plasma [145]. As ART only blocks the infection of new cells, but not viral RNA transcription in cells infected before the start of therapy, the observed association of decreased ART pressure with increased usRNA levels in PBMC, in the absence of virological rebound in plasma, strongly suggests new replication cycles despite ART. Therefore, if an average ART-treated patient takes $\sim 75 \%$ of the prescribed doses [146], our results suggest that most patients experience bursts of residual replication at some point during treatment. In most patients, these bursts of residual virus replication are probably self-limiting and therefore they do not lead to the development of drug resistance and therapy failure [90,147]. However, even if no ART failure is observed, low-level virus replication can trigger immune activation, with all the potentially morbid consequences thereof (see above).

Notwithstanding its importance, this residual virus replication, despite being readily detectable by quantifying CA HIV RNA, goes unnoticed in the clinic, where ART responses are monitored using commercial plasma viral load assays. This could simply be a sensitivity issue, i.e. ultrasensitive assays for plasma viremia [86] may also be able to detect these effects. Alternatively, CA viral RNA may be an intrinsically more suitable marker for monitoring therapy responses, e.g. because residual replication may occur by cell-to-cell transfer. By mathematical modeling and in vitro analysis, it was recently suggested that ART is much less efficient in preventing cell-to-cell HIV transfer that it is in stopping infection of cells by free virions [148]. If residual virus replication indeed occurs by cell-to-cell transfer in patients on ART, then CA HIV RNA is obviously a much more suitable biomarker to monitor this process than viral RNA in plasma.

Cell-to-cell HIV transfer is expected to preferentially occur in tissues (predominantly lymphoid tissues and gastrointestinal tract), where cell contacts are much more abundant, and where much higher viral DNA and CA RNA loads have consistently been found, than in peripheral blood [33,52,55,149-153]. Furthermore, three collaborating laboratories recently demonstrated both suboptimal drug penetration and high HIV levels in tissues compared to blood [154]. This finding might suggest that suppression of HIV replication in peripheral blood (as assessed by monitoring plasma viremia only) is "misleading" [154] in that it does not reflect ongoing viral replication in the tissues. Although it is clear that in order to get the full picture, one should look into tissues as well, it should be noted that unlike plasma viremia, CA HIV RNA level in PBMC is an excellent indicator of CA HIV RNA load in lymphoid tissue [55]. This can be due both to the constant trafficking of infected cells between tissues and peripheral blood and the extended half-life of infected cells compared to free virions, which can also be trapped in the follicular dendritic cell network [34]. In line with this reasoning, a recent study failed to show any compartmentalization of sequences derived from CA HIV RNA and DNA between the gut and peripheral blood [155], confirming the constant communication between these compartments [149].

Based on the evidence discussed above, we can speculate that monitoring ART response in peripheral blood may become less "misleading" if alternative HIV biomarkers are used for this purpose. Indeed, a number of studies recently attempted to demonstrate residual replication by observing the changes in plasma viremia, monitored with ultrasensitive assays, upon ART intensification with raltegravir [74,156,157], but no significant effects on plasma viremia were reported. In contrast, two reports documented a decrease in CA HIV RNA and a transient increase in 2-LTR circles (a form of episomal HIV DNA) upon the same intervention $[143,158]$. Notably, the two latter studies also failed to detect any effect of raltegravir intensification on plasma viremia. This difference may be partly explained by the fact that cell-associated HIV biomarkers more directly reflect virus replication, whereas plasma viremia is dependent not only on virus production but also on virus clearance. It remains to be established whether virus clearance is indeed more efficient and the half-life of free virions is indeed much shorter in patients on ART than in untreated patients (see above). However, if this is the case, then it may explain why it proved impossible to detect any (presumably small) decrease in virus production upon therapy intensification by measuring plasma viremia only, at least with infrequent sampling. Likewise, it could explain our observations of an increased CA HIV RNA level in suboptimal adherers in the absence of any virological rebound in plasma [145]. Therefore, even when cell-to-cell virus transfer is not taken into consideration, cell-associated viral markers may be more appropriate for monitoring ART responses than plasma viremia. 
Besides CA HIV RNA, episomal viral DNA (e.g. in the form of 2-LTR circles) has been suggested as a biomarker of residual replication under ART [159]. This was based on the observed labile nature of 2-LTR circles, which thus could signify recently infected cells $[159,160]$. However, other studies failed to confirm the labile nature of 2-LTR circles $[110,161,162]$. Remarkably, transient accumulation of 2-LTR circles was demonstrated upon ART intensification with raltegravir, strongly suggesting that these episomal DNA molecules were derived from cells that had been recently infected despite ART [158]. Raltegravir treatment also reduced T-cell activation, which was higher at baseline in subjects with detectable 2-LTR circles $[158,163]$. However, these effects could not be reproduced by others, possibly due to the differences in sampling times or other methodological variations $[164,165]$. More recently, sequences derived from episomal HIV DNA but not from proviral DNA in patients on ART just prior to therapy interruption were shown to match those in rebounding virus after therapy interruption [166], emphasizing the dynamic nature of this marker. However, an earlier study failed to detect any significant shifts in the levels of 2-LTR circles during 2 weeks of structured treatment interruption, whereas clear shifts in CA usRNA were observed, suggesting that usRNA is a more dynamic and sensitive marker of HIV replication than 2-LTR circles [110].

When it comes to monitoring ART responses, one marker should not necessarily exclude the others. Both CA HIV RNA and episomal viral DNA have been linked to residual virus replication; therefore, if these two biomarkers are measured in parallel in a patient on ART, there is a better chance of timely identifying future ART complications (e.g. therapy failure due to suboptimal adherence) and indicating a clinical or behavioral intervention. In general, monitoring several biomarkers in parallel with sensitive assays, compared to the current clinical practice of relying on one virological marker only, which is measured with suboptimal sensitivity, would allow much better understanding, and ultimately control, of viral persistence in patients on therapy.

\section{Potential use of CA HIV RNA assays for HIV eradication strategies}

The "gold standard" in measurement of replicationcompetent HIV reservoir is the quantitative coculture assay that determines an IUPM value [5]. However, this assay is labor-intensive, time-consuming, expensive, and requires large blood volumes (frequently obtainable only by leukapheresis). Therefore, alternative assays are urgently needed to support large-scale clinical trials exploring the effectiveness of HIV eradication strategies [5-8]. Several relatively easy-to-perform PCR-based assays have been developed for different HIV biomarkers, but it is still unclear which biomarker/assay can serve as a reliable surrogate for IUPM. Measurement of integrated DNA will not distinguish replication-defective from replication-competent virus, and quantitation of CA RNA (the "active HIV reservoir") will miss cells that harbor transcriptionally silent proviruses but that can be activated to produce infectious virus (the "activatable HIV reservoir"). In any case, bulk assays will probably be of limited value to quantify frequencies of cells harboring replication-competent HIV: such a "magic bullet" assay should be performed at the limiting dilution or single-cell level.

One of the primary HIV eradication strategies that is currently being tested in clinical trials is reactivation of the latent viral reservoir by inducing virus production from latently infected cells using e.g. histone deacetylase inhibitors (HDACi) or other agents [5-7]. In vitro, the potency of these agents can easily be screened, but to test the efficacy of such compounds in vivo (or ex vivo), an assay should be used that measures reactivation of virus production in patients on ART. In this respect, it is important to determine which viral biomarker most adequately reflects virus production. As discussed above, plasma viremia reflects a balance between virus production and clearance (and the latter may depend on the viral load), some CA RNA ${ }^{+}$cells may not produce virus, and the extracellular fraction of CA RNA does not necessarily originate from the attached cell. Still, in a recently published study that demonstrated the disruption of latency by vorinostat (an $\mathrm{HDACi}$ ) in resting $\mathrm{CD}^{+} \mathrm{T}$ cells of patients on ART, CA HIV usRNA was used as an outcome measure [167]. Remarkably, in each of the eight participants, vorinostat caused an increase in both biomarkers of cellular acetylation and HIV usRNA [167], suggesting the usefulness of CA HIV RNA for monitoring the effectiveness of virus eradication strategies.

\section{Conclusions}

Ultrasensitive measurement of plasma viremia has provided many important insights into HIV persistence during ART. Yet, to fully characterize the dynamics of viral reservoirs in patients on ART, sensitive and precise assays to quantify cell-associated HIV biomarkers are urgently needed. The observations discussed in this review suggest that CA HIV RNA is a promising candidate for the role of an alternative biomarker to be used in monitoring the virological response to ART and to novel HIV eradication strategies. However, more research is necessary to confirm these exciting observations. In particular, assay standardization is warranted, as the reproducibility across multiple laboratories is unknown. Therefore, comparative studies must be conducted to identify the most robust CA HIV RNA assay. In the ideal situation, such an assay should be HIV subtype-independent and 
capable of quantitation of CA viral RNA expression at the single-cell level. Further studies are also warranted in order to establish whether CA HIV RNA can be used as a reliable biomarker of persistent low-level virus replication/production in patients on suppressive ART. Furthermore, monitoring several biomarkers in parallel should provide advantages by increasing the assay robustness and sensitivity. In summary, novel, dynamic, viral biomarkers have to be characterized and assays to quantify them have to be developed, if our understanding of the virological processes in patients on ART is once to be taken "beyond undetectability".

\section{Competing interests}

The authors declare that they have no competing interests.

\section{Authors' contributions}

AOP wrote the manuscript. BB and WL modified parts of the manuscript. All authors read and approved the final manuscript.

\section{Acknowledgements}

This work was financially supported by the AIDS Fonds Netherlands.

Received: 12 February 2013 Accepted: 10 April 2013

Published: 15 April 2013

\section{References}

1. Piatak M Jr, Saag MS, Yang LC, Clark SJ, Kappes JC, Luk KC, Hahn BH, Shaw GM, Lifson JD: High levels of HIV-1 in plasma during all stages of infection determined by competitive PCR. Science 1993, 259:1749-1754.

2. Siliciano JD, Siliciano RF: Biomarkers of HIV replication. Curr Opin HIV AIDS 2010, 5:491-497

3. Doyle T, Geretti AM: Low-level viraemia on HAART: significance and management. Curr Opin Infect Dis 2012, 25:17-25.

4. Deeks SG, Autran B, Berkhout B, Benkirane M, Cairns S, Chomont N, Chun TW, Churchill M, Mascio MD, Katlama C, et al: Towards an HIV cure: a global scientific strategy. Nat Rev Immunol 2012, 12:607-614

5. Lewin SR, Rouzioux C: HIV cure and eradication: how will we get from the laboratory to effective clinical trials? AIDS 2011, 25:885-897.

6. Lafeuillade A: Eliminating the HIV reservoir. Curr HIV/AIDS Rep 2012, 9:121-131.

7. Smith MZ, Wightman F, Lewin SR: HIV reservoirs and strategies for eradication. Curr HIV/AIDS Rep 2012, 9:5-15.

8. Hilldorfer BB, Cillo AR, Besson GJ, Bedison MA, Mellors JW: New tools for quantifying HIV-1 reservoirs: plasma RNA single copy assays and beyond. Curr HIV/AIDS Rep 2012, 9:91-100.

9. Avettand-Fenoel V, Chaix ML, Blanche S, Burgard M, Floch C, Toure K, Allemon MC, Warszawski J, Rouzioux C: LTR real-time PCR for HIV-1 DNA quantitation in blood cells for early diagnosis in infants born to seropositive mothers treated in HAART area (ANRS CO 01). J Med Virol 2009, 81:217-223.

10. Pace MJ, Agosto L, Graf EH, O'Doherty U: HIV reservoirs and latency models. Virology 2011, 411:344-354.

11. Sloan RD, Wainberg MA: The role of unintegrated DNA in HIV infection. Retrovirology 2011, 8:52.

12. Furtado MR, Callaway DS, Phair JP, Kunstman KJ, Stanton JL, Macken CA, Perelson AS, Wolinsky SM: Persistence of HIV-1 transcription in peripheralblood mononuclear cells in patients receiving potent antiretroviral therapy. N Engl J Med 1999, 340:1614-1622.

13. Schwartz S, Felber BK, Benko DM, Fenyo EM, Pavlakis GN: Cloning and functional analysis of multiply spliced mRNA species of human immunodeficiency virus type 1. J Virol 1990, 64:2519-2529.

14. Purcell DF, Martin MA: Alternative splicing of human immunodeficiency virus type 1 mRNA modulates viral protein expression, replication, and infectivity. J Virol 1993, 67:6365-6378.

15. Kim SY, Byrn R, Groopman J, Baltimore D: Temporal aspects of DNA and RNA synthesis during human immunodeficiency virus infection: evidence for differential gene expression. J Virol 1989, 63:3708-3713.
16. Cullen BR, Greene WC: Regulatory pathways governing HIV-1 replication. Cell 1989, 58:423-426.

17. Karn J, Stoltzfus CM: Transcriptional and Posttranscriptional Regulation of HIV-1 Gene Expression. Cold Spring Harb Perspect Med 2012, 2:a006916.

18. Malim MH, Hauber J, Le SY, Maizel JV, Cullen BR: The HIV-1 rev transactivator acts through a structured target sequence to activate nuclear export of unspliced viral mRNA. Nature 1989, 338:254-257.

19. Malim MH, Cullen BR: HIV-1 structural gene expression requires the binding of multiple Rev monomers to the viral RRE: implications for HIV1 latency. Cell 1991, 65:241-248.

20. Exline CM, Feng Z, Stoltzfus CM: Negative and positive mRNA splicing elements act competitively to regulate human immunodeficiency virus type 1 vif gene expression. J Virol 2008, 82:3921-3931.

21. Pollard WW, Malim MH: The HIV-1 Rev protein. Annu Rev Microbiol 1998, 52:491-532.

22. Schnittman SM, Greenhouse JJ, Lane HC, Pierce PF, Fauci AS: Frequent detection of HIV-1-specific mRNAs in infected individuals suggests ongoing active viral expression in all stages of disease. AIDS Res Hum Retroviruses 1991, 7:361-367.

23. Michael NL, Vahey M, Burke DS, Redfield RR: Viral DNA and mRNA expression correlate with the stage of human immunodeficiency virus (HIV) type 1 infection in humans: evidence for viral replication in all stages of HIV disease. J Virol 1992, 66:310-316.

24. Seshamma T, Bagasra O, Trono D, Baltimore D, Pomerantz RJ: Blocked early-stage latency in the peripheral blood cells of certain individuals infected with human immunodeficiency virus type 1. Proc Natl Acad Sci U S A 1992, 89:10663-10667.

25. Bagnarelli P, Menzo S, Valenza A, Manzin A, Giacca M, Ancarani F, Scalise G, Varaldo $\mathrm{PE}$, Clementi M: Molecular profile of human immunodeficiency virus type 1 infection in symptomless patients and in patients with AIDS. J Virol 1992, 66:7328-7335.

26. Graziosi C, Pantaleo G, Butini L, Demarest JF, Saag MS, Shaw GM, Fauci AS: Kinetics of human immunodeficiency virus type 1 (HIV-1) DNA and RNA synthesis during primary HIV-1 infection. Proc Natl Acad Sci U S A 1993, 90:6405-6409.

27. Furtado MR, Murphy R, Wolinsky SM: Quantification of human immunodeficiency virus type 1 tat mRNA as a marker for assessing the efficacy of antiretroviral therapy. J Infect Dis 1993, 167:213-216.

28. Gupta P, Kingsley L, Armstrong J, Ding M, Cottrill M, Rinaldo C: Enhanced expression of human immunodeficiency virus type 1 correlates with development of AIDS. Virology 1993, 196:586-595.

29. Patterson BK, Till M, Otto P, Goolsby C, Furtado MR, McBride $L$, Wolinsky SM: Detection of HIV-1 DNA and messenger RNA in individual cells by PCR-driven in situ hybridization and flow cytometry. Science 1993, 260:976-979.

30. Arens M, Joseph T, Nag S, Miller JP, Powderly WG, Ratner L: Alterations in spliced and unspliced HIV-1-specific RNA detection in peripheral blood mononuclear cells of individuals with varying CD4-positive lymphocyte counts. AIDS Res Hum Retroviruses 1993, 9:1257-1263.

31. Embretson J, Zupancic M, Ribas JL, Burke A, Racz P, Tenner-Racz K, Haase AT: Massive covert infection of helper T lymphocytes and macrophages by HIV during the incubation period of AIDS. Nature 1993, 362:359-362.

32. Embretson J, Zupancic M, Beneke J, Till M, Wolinsky S, Ribas JL, Burke A, Haase AT: Analysis of human immunodeficiency virus-infected tissues by amplification and in situ hybridization reveals latent and permissive infections at single-cell resolution. Proc Natl Acad Sci U S A 1993, 90:357-361.

33. Pantaleo G, Graziosi C, Demarest JF, Butini L, Montroni M, Fox CH, Orenstein $\mathrm{JM}$, Kotler DP, Fauci AS: HIV infection is active and progressive in lymphoid tissue during the clinically latent stage of disease. Nature 1993, 362:355-358.

34. Haase AT, Henry K, Zupancic M, Sedgewick G, Faust RA, Melroe H, Cavert W, Gebhard K, Staskus K, Zhang ZQ, et al: Quantitative image analysis of HIV1 infection in lymphoid tissue. Science 1996, 274:985-989.

35. Brachtel EF, Mascola JR, Wear DJ, Ehrenberg PK, Dayhoff DE, Sanders-Buell E, Michael NL, Frankel SS: Demonstration of de novo HIV type 1 production by detection of multiply spliced and unspliced HIV type 1 RNA in paraffin-embedded tonsils. AIDS Res Hum Retroviruses 2002, 18:785-790.

36. Saksela K, Stevens CE, Rubinstein P, Taylor PE, Baltimore D: HIV-1 messenger RNA in peripheral blood mononuclear cells as an early marker of risk for progression to AIDS. Ann Intern Med 1995, 123:641-648.

37. Mellors JW, Rinaldo CR Jr, Gupta P, White RM, Todd JA, Kingsley LA: Prognosis in HIV-1 infection predicted by the quantity of virus in plasma. Science 1996, 272:1167-1170. 
38. Mellors JW, Munoz A, Giorgi JV, Margolick JB, Tassoni CJ, Gupta P, Kingsley LA, Todd JA, Saah AJ, Detels R, et al: Plasma viral load and CD4+ lymphocytes as prognostic markers of HIV-1 infection. Ann Intern Med 1997, 126:946-954.

39. Henrard DR, Phillips JF, Muenz LR, Blattner WA, Wiesner D, Eyster ME, Goedert JJ: Natural history of HIV-1 cell-free viremia. JAMA 1995, 274:554-558.

40. de Wolf F, Spijkerman I, Schellekens PT, Langendam M, Kuiken C, Bakker M Roos M, Coutinho R, Miedema F, Goudsmit J: AIDS prognosis based on HIV-1 RNA, CD4+ T-cell count and function: markers with reciprocal predictive value over time after seroconversion. AIDS 1997, 11:1799-1806.

41. Sabin CA, Devereux H, Phillips AN, Hill A, Janossy G, Lee CA, Loveday C: Course of viral load throughout HIV-1 infection. J Acquir Immune Defic Syndr 2000, 23:172-177.

42. Furtado MR, Kingsley LA, Wolinsky SM: Changes in the viral mRNA expression pattern correlate with a rapid rate of CD4+ T-cell number decline in human immunodeficiency virus type 1-infected individuals. $J$ Virol 1995, 69:2092-2100.

43. Saltarelli MJ, Hadziyannis E, Hart CE, Harrison JV, Felber BK, Spira TJ, Pavlakis GN: Analysis of human immunodeficiency virus type $1 \mathrm{mRNA}$ splicing patterns during disease progression in peripheral blood mononuclear cells from infected individuals. AIDS Res Hum Retroviruses 1996, 12:1443-1456.

44. Pasternak AO, Jurriaans S, Bakker M, Berkhout B, Lukashov W: Steady increase in cellular HIV-1 load during the asymptomatic phase of untreated infection despite stable plasma viremia. AIDS 2010, 24:1641-1649.

45. Saksela K, Stevens C, Rubinstein P, Baltimore D: Human immunodeficiency virus type 1 mRNA expression in peripheral blood cells predicts disease progression independently of the numbers of CD4+ lymphocytes. ProC Natl Acad Sci U S A 1994, 91:1104-1108.

46. Michael NL, Mo T, Merzouki A, O'Shaughnessy M, Oster C, Burke DS, Redfield RR, Birx DL, Cassol SA: Human immunodeficiency virus type 1 cellular RNA load and splicing patterns predict disease progression in a longitudinally studied cohort. J Virol 1995, 69:1868-1877.

47. Comar M, Simonelli C, Zanussi S, Paoli P, Vaccher E, Tirelli U, Giacca M: Dynamics of HIV-1 mRNA expression in patients with long-term nonprogressive HIV-1 infection. J Clin Invest 1997, 100:893-903.

48. Pomerantz RJ, Trono D, Feinberg MB, Baltimore D: Cells nonproductively infected with HIV-1 exhibit an aberrant pattern of viral RNA expression: a molecular model for latency. Cell 1990, 61:1271-1276.

49. Michael NL, Morrow P, Mosca J, Vahey M, Burke DS, Redfield RR: Induction of human immunodeficiency virus type 1 expression in chronically infected cells is associated primarily with a shift in RNA splicing patterns. $J$ Virol 1991, 65:7084

50. Huynen MA, Neumann AU: Rate of killing of HIV-infected T cells and disease progression. Science 1996, 272:1962

51. Wolinsky SM, Korber BT, Neumann AU, Daniels M, Kunstman KJ, Whetsell AJ, Furtado MR, Cao Y, Ho DD, Safrit JT: Adaptive evolution of human immunodeficiency virus-type 1 during the natural course of infection. Science 1996, 272:537-542.

52. Wong JK, Gunthard HF, Havlir DV, Zhang ZQ, Haase AT, Ignacio CC, Kwok S, Emini E, Richman DD: Reduction of HIV-1 in blood and lymph nodes following potent antiretroviral therapy and the virologic correlates of treatment failure. Proc Natl Acad Sci U S A 1997, 94:12574-12579.

53. Gunthard HF, Wong JK, Ignacio CC, Guatelli JC, Riggs NL, Havlir DV, Richman DD: Human immunodeficiency virus replication and genotypic resistance in blood and lymph nodes after a year of potent antiretroviral therapy. $J$ Virol 1998, 72:2422-2428

54. Markowitz M, Vesanen M, Tenner-Racz K, Cao Y, Binley JM, Talal A, Hurley A, Jin X, Chaudhry MR, Yaman M, et al: The effect of commencing combination antiretroviral therapy soon after human immunodeficiency virus type 1 infection on viral replication and antiviral immune responses. J Infect Dis 1999, 179:527-537.

55. Yerly S, Rutschmann OT, Opravil M, Marchal F, Hirschel B, Perrin L: Cellassociated HIV-1 RNA in blood as indicator of virus load in lymph nodes. The Swiss HIV Cohort Study. J Infect Dis 1999, 180:850-853.

56. Natarajan V, Bosche M, Metcalf JA, Ward DJ, Lane HC, Kovacs JA: HIV-1 replication in patients with undetectable plasma virus receiving HAART. Highly active antiretroviral therapy. Lancet 1999, 353:119-120.

57. Hockett RD, Kilby JM, Derdeyn CA, Saag MS, Sillers M, Squires K, Chiz S, Nowak MA, Shaw GM, Bucy RP: Constant mean viral copy number per infected cell in tissues regardless of high, low, or undetectable plasma HIV RNA. J Exp Med 1999, 189:1545-1554.
58. Lewin SR, Vesanen M, Kostrikis L, Hurley A, Duran M, Zhang L, Ho DD, Markowitz M: Use of real-time PCR and molecular beacons to detect virus replication in human immunodeficiency virus type 1-infected individuals on prolonged effective antiretroviral therapy. J Virol 1999, 73:6099-6103

59. Fischer M, Gunthard HF, Opravil M, Joos B, Huber W, Bisset LR, Ott P, Boni J, Weber R, Cone RW: Residual HIV-RNA levels persist for up to 2.5 years in peripheral blood mononuclear cells of patients on potent antiretroviral therapy. AIDS Res Hum Retroviruses 2000, 16:1135-1140.

60. Gunthard HF, Havlir DV, Fiscus S, Zhang ZQ, Eron J, Mellors J, Gulick R, Frost SD, Brown AJ, Schleif W, et al: Residual human immunodeficiency virus (HIV) Type 1 RNA and DNA in lymph nodes and HIV RNA in genital secretions and in cerebrospinal fluid after suppression of viremia for 2 years. J Infect Dis 2001, 183:1318-1327.

61. Patterson BK, McCallister S, Schutz M, Siegel JN, Shults K, Flener Z, Landay A: Persistence of intracellular HIV-1 mRNA correlates with HIV-1-specific immune responses in infected subjects on stable HAART. AIDS 2001, 15:1635-1641.

62. Zhang J, Crumpacker CS: Human immunodeficiency virus type 1 RNA in peripheral blood mononuclear cells of patients receiving prolonged highly active antiretroviral therapy. J Infect Dis 2001, 184:1341-1344.

63. Zhu T, Muthui D, Holte S, Nickle D, Feng F, Brodie S, Hwangbo Y, Mullins JI, Corey L: Evidence for human immunodeficiency virus type 1 replication in vivo in $\mathrm{CD} 14(+)$ monocytes and its potential role as a source of virus in patients on highly active antiretroviral therapy. J Virol 2002, 76:707-716.

64. Chun TW, Justement JS, Lempicki RA, Yang J, Dennis G Jr, Hallahan CW, Sanford C, Pandya P, Liu S, McLaughlin M, et al: Gene expression and viral production in latently infected, resting CD4+ T cells in viremic versus aviremic HIV-infected individuals. Proc Natl Acad Sci U S A 2003, 100:1908-1913.

65. Fischer M, Joos B, Hirschel B, Bleiber G, Weber R, Gunthard HF: Cellular viral rebound after cessation of potent antiretroviral therapy predicted by levels of multiply spliced HIV-1 RNA encoding nef. J Infect Dis 2004, 190:1979-1988.

66. Zanchetta M, Walker S, Burighel N, Bellanova D, Rampon O, Giaquinto C, De Rossi A: Long-term decay of the HIV-1 reservoir in HIV-1-infected children treated with highly active antiretroviral therapy. J Infect Dis 2006, 193:1718-1727.

67. Kaiser $\mathrm{P}$, Joos B, Niederost B, Weber R, Gunthard HF, Fischer M: Productive human immunodeficiency virus type 1 infection in peripheral blood predominantly takes place in CD4/CD8 double-negative T lymphocytes. J Virol 2007, 81:9693-9706.

68. Soares RS, Matoso P, Calado M, Sousa AE: Strategies to quantify unspliced and multiply spliced mRNA expression in HIV-2 infection. J Virol Methods 2011, 175:38-45

69. Pasternak AO, Adema KW, Bakker M, Jurriaans S, Berkhout B, Cornelissen M, Lukashov W: Highly sensitive methods based on seminested real-time reverse transcription-PCR for quantitation of human immunodeficiency virus type 1 unspliced and multiply spliced RNA and proviral DNA. J Clin Microbiol 2008, 46:2206-2211.

70. Pasternak AO, Jurriaans S, Bakker M, Prins JM, Berkhout B, Lukashov W: Cellular levels of HIV unspliced RNA from patients on combination antiretroviral therapy with undetectable plasma viremia predict the therapy outcome. PLOS One 2009, 4:e8490.

71. Fischer M, Huber W, Kallivroussis A, Ott P, Opravil M, Luthy R, Weber R, Cone RW: Highly sensitive methods for quantitation of human immunodeficiency virus type 1 RNA from plasma, cells, and tissues. J Clin Microbiol 1999, 37:1260-1264.

72. Kupfer B, Matz B, Daumer MP, Roden F, Rockstroh JK, Qurishi N, Spengler $U$, Kaiser R: Frequent detection of cell-associated HIV-1 RNA in patients with plasma viral load $<50$ copies/ml. J Med Virol 2007 79:1440-1445

73. Patterson BK, Carlo DJ, Kaplan MH, Marecki M, Pawha S, Moss RB: Cellassociated HIV-1 messenger RNA and DNA in T-helper cell and monocytes in asymptomatic HIV-1-infected subjects on HAART plus an inactivated HIV-1 immunogen. AIDS 1999, 13:1607-1611.

74. Hatano H, Hayes TL, Dahl V, Sinclair E, Lee TH, Hoh R, Lampiris H, Hunt PW, Palmer S, McCune JM, et al: A randomized, controlled trial of raltegravir intensification in antiretroviral-treated, HIV-infected patients with a suboptimal CD4+ T cell response. J Infect Dis 2011, 203:960-968.

75. Kuchipudi SV, Tellabati M, Nelli RK, White GA, Perez BB, Sebastian S, Slomka MJ, Brookes SM, Brown IH, Dunham SP, et al: 18S rRNA is a reliable 
normalisation gene for real time PCR based on influenza virus infected cells. Virol J 2012, 9:230.

76. Gompels M, Dunn DT, Phillips A, Dooley D, De Burgh TA, Anderson J, Post F, Pillay D, Gazzard B, Hill T, et al: Does discordancy between the CD4 count and CD4 percentage in HIV-positive individuals influence outcomes on highly active antiretroviral therapy? J Infect Dis 2012, 205:540-547.

77. Kwok S, Kellogg DE, McKinney N, Spasic D, Goda L, Levenson C, Sninsky JJ: Effects of primer-template mismatches on the polymerase chain reaction: human immunodeficiency virus type 1 model studies. Nucleic Acids Res 1990, 18:999-1005.

78. Bru D, Martin-Laurent F, Philippot L: Quantification of the detrimental effect of a single primer-template mismatch by real-time PCR using the $16 \mathrm{~S}$ rRNA gene as an example. Appl Environ Microbiol 2008, 74:1660-1663.

79. Suss B, Flekna G, Wagner M, Hein I: Studying the effect of single mismatches in primer and probe binding regions on amplification curves and quantification in real-time PCR. J Microbiol Methods 2009, 76:316-319.

80. Korn K, Weissbrich B, Henke-Gendo C, Heim A, Jauer CM, Taylor N, Eberle J: Single-point mutations causing more than 100-fold underestimation of human immunodeficiency virus type 1 (HIV-1) load with the Cobas TaqMan HIV-1 real-time PCR assay. J Clin Microbiol 2009, 47:1238-1240.

81. Desire N, Dehee A, Schneider V, Jacomet C, Goujon C, Girard PM, Rozenbaum W, Nicolas JC: Quantification of human immunodeficiency virus type 1 proviral load by a TaqMan real-time PCR assay. J Clin Microbiol 2001, 39:1303-1310

82. Kondo M, Sudo K, Tanaka R, Sano T, Sagara H, Iwamuro S, Takebe Y, Imai M, Kato S: Quantitation of HIV-1 group M proviral DNA using TaqMan MGB real-time PCR. J Virol Methods 2009, 157:141-146.

83. Rozera G, Abbate I, Bruselles A, Bartolini B, D'Offizi G, Nicastri E, Tommasi C, Capobianchi MR: Comparison of real-time PCR methods for measurement of HIV-1 proviral DNA. J Virol Methods 2010, 164:135-138.

84. van der Sluis RM, van Montfort T, Centlivre M, Schopman NC, Cornelissen M, Sanders RW, Berkhout B, Jeeninga RE, Paxton WA, Pollakis G: Quantitation of HIV-1 DNA with a sensitive TaqMan assay that has broad subtype specificity. J Virol Methods 2013, 187:94-102.

85. Schmid A, Gianella S, von Wyl V, Metzner KJ, Scherrer AU, Niederost B, Althaus CF, Rieder P, Grube C, Joos B, et al: Profound depletion of HIV-1 transcription in patients initiating antiretroviral therapy during acute infection. PLoS One 2010, 5:e13310.

86. Palmer S, Wiegand AP, Maldarelli F, Bazmi H, Mican JM, Polis M, Dewar RL, Planta A, Liu S, Metcalf JA, et al: New real-time reverse transcriptaseinitiated PCR assay with single-copy sensitivity for human immunodeficiency virus type 1 RNA in plasma. J Clin Microbiol 2003, 41:4531-4536

87. Dornadula G, Zhang H, VanUitert B, Stern J, Livornese L Jr, Ingerman MJ, Witek J, Kedanis RJ, Natkin J, DeSimone J, et al: Residual HIV-1 RNA in blood plasma of patients taking suppressive highly active antiretroviral therapy. JAMA 1999, 282:1627-1632.

88. Di Mascio M, Dornadula G, Zhang H, Sullivan J, Xu Y, Kulkosky J, Pomerantz RJ, Perelson AS: In a subset of subjects on highly active antiretroviral therapy, human immunodeficiency virus type 1 RNA in plasma decays from 50 to $<5$ copies per milliliter, with a half-life of 6 months. J Virol 2003, 77:2271-2275

89. Palmisano L, Giuliano M, Nicastri E, Pirillo MF, Andreotti M, Galluzzo CM, Bucciardini R, Fragola V, Andreoni M, Vella S: Residual viraemia in subjects with chronic HIV infection and viral load < 50 copies/ml: the impact of highly active antiretroviral therapy. AIDS 2005, 19:1843-1847.

90. Havlir DV, Bassett R, Levitan D, Gilbert P, Tebas P, Collier AC, Hirsch MS, Ignacio C, Condra J, Gunthard HF, et al: Prevalence and predictive value of intermittent viremia with combination HIV therapy. JAMA 2001, 286:171-179.

91. Yerly S, Kaiser L, Perneger TV, Cone RW, Opravil M, Chave JP, Furrer H, Hirschel B, Perrin L: Time of initiation of antiretroviral therapy: impact on HIV-1 viraemia. The Swiss HIV Cohort Study. AIDS 2000, 14:243-249.

92. Maldarelli F, Palmer S, King MS, Wiegand A, Polis MA, Mican J, Kovacs JA, Davey RT, Rock-Kress D, Dewar R, et al: ART suppresses plasma HIV-1 RNA to a stable set point predicted by pretherapy viremia. PLoS Pathog 2007, 3:e46.

93. Palmer S, Maldarelli F, Wiegand A, Bernstein B, Hanna GJ, Brun SC, Kempf DJ, Mellors JW, Coffin JM, King MS: Low-level viremia persists for at least 7 years in patients on suppressive antiretroviral therapy. Proc Natl Acad Sci U S A 2008, 105:3879-3884.
94. Bagnarelli P, Valenza A, Menzo S, Sampaolesi R, Varaldo PE, Butini L, Montroni M, Perno CF, Aquaro S, Mathez D, et al: Dynamics and modulation of human immunodeficiency virus type 1 transcripts in vitro and in vivo. J Virol 1996, 70:7603-7613.

95. Burgisser P, Spertini F, Weyrich-Suter C, Pagani JL, Meylan PR: Monitoring responses to antiretroviral treatment in human immunodeficiency virus type 1 (HIV-1)-infected patients by serial lymph node aspiration. $J$ Infect Dis 1997, 175:1202-1205.

96. Garrigue I, Pellegrin I, Hoen B, Dumon B, Harzic M, Schrive MH, Sereni D, Fleury H: Cell-associated HIV-1-DNA quantitation after highly active antiretroviral therapy-treated primary infection in patients with persistently undetectable plasma HIV-1 RNA. AIDS 2000, 14:2851-2855.

97. Yerly S, Perneger TV, Vora S, Hirschel B, Perrin L: Decay of cell-associated HIV-1 DNA correlates with residual replication in patients treated during acute HIV-1 infection. AIDS 2000, 14:2805-2812.

98. Hoen B, Cooper DA, Lampe FC, Perrin L, Clumeck N, Phillips AN, Goh LE, Lindback S, Sereni D, Gazzard B, et al: Predictors of virological outcome and safety in primary HIV type 1-infected patients initiating quadruple antiretroviral therapy: QUEST GW PROB3005. Clin Infect Dis 2007, 45:381-390.

99. Perelson AS, Neumann AU, Markowitz M, Leonard JM, Ho DD: HIV-1 dynamics in vivo: virion clearance rate, infected cell life-span, and viral generation time. Science 1996, 271:1582-1586.

100. Ramratnam B, Bonhoeffer S, Binley J, Hurley A, Zhang L, Mittler JE, Markowitz M, Moore JP, Perelson AS, Ho DD: Rapid production and clearance of HIV-1 and hepatitis C virus assessed by large volume plasma apheresis. Lancet 1999, 354:1782-1785.

101. Finzi D, Siliciano RF: Viral dynamics in HIV-1 infection. Cell 1998, 93:665-671.

102. Wodarz D, Nowak MA: Mathematical models of HIV pathogenesis and treatment. Bioessays 2002, 24:1178-1187.

103. Lassen KG, Ramyar KX, Bailey JR, Zhou Y, Siliciano RF: Nuclear retention of multiply spliced HIV-1 RNA in resting CD4+ T cells. PLOS Pathog 2006, 2:e68

104. Dandri M, Murray JM, Lutgehetmann M, Volz T, Lohse AW, Petersen J: Virion half-life in chronic hepatitis B infection is strongly correlated with levels of viremia. Hepatology 2008, 48:1079-1086.

105. Zhang L, Dailey PJ, He T, Gettie A, Bonhoeffer S, Perelson AS, Ho DD: Rapid clearance of simian immunodeficiency virus particles from plasma of rhesus macaques. J Virol 1999, 73:855-860.

106. Igarashi T, Brown C, Azadegan A, Haigwood N, Dimitrov D, Martin MA, Shibata R: Human immunodeficiency virus type 1 neutralizing antibodies accelerate clearance of cell-free virions from blood plasma. Nat Med 1999, 5:211-216

107. Morris MK, Katzenstein DA, Israelski D, Zolopa A, Hendry RM, Hanson CV: Characterization of the HIV-1 specific humoral immune response during highly active antiretroviral therapy (HAART). J Acquir Immune Defic Syndr 2001, 28:405-415.

108. Bailey JR, Lassen KG, Yang HC, Quinn TC, Ray SC, Blankson JN, Siliciano RF: Neutralizing antibodies do not mediate suppression of human immunodeficiency virus type 1 in elite suppressors or selection of plasma virus variants in patients on highly active antiretroviral therapy. J Virol 2006, 80:4758-4770.

109. Fischer M, Wong JK, Russenberger D, Joos B, Opravil M, Hirschel B, Trkola A, Kuster H, Weber R, Gunthard HF: Residual cell-associated unspliced HIV-1 RNA in peripheral blood of patients on potent antiretroviral therapy represents intracellular transcripts. Antivir Ther 2002, 7:91-103.

110. Fischer $M$, Trkola $A$, Joos $B$, Hafner $R$, Joller $H$, Muesing MA, Kaufman DR, Berli E, Hirschel B, Weber R, et al: Shifts in cell-associated HIV-1 RNA but not in episomal HIV-1 DNA correlate with new cycles of HIV-1 infection in vivo. Antivir Ther 2003, 8:97-104.

111. Fischer M, Joos B, Wong JK, Ott P, Opravil M, Hirschel B, Weber R, Gunthard HF: Attenuated and nonproductive viral transcription in the lymphatic tissue of HIV-1-infected patients receiving potent antiretroviral therapy. J Infect Dis 2004, 189:273-285.

112. Fischer $M$, Joos B, Niederost B, Kaiser $P$, Hafner R, von Wyl V, Ackermann M, Weber R, Gunthard HF: Biphasic decay kinetics suggest progressive slowing in turnover of latently HIV-1 infected cells during antiretroviral therapy. Retrovirology 2008, 5:107.

113. Siliciano JD, Kajdas J, Finzi D, Quinn TC, Chadwick K, Margolick JB, Kovacs C, Gange SJ, Siliciano RF: Long-term follow-up studies confirm the stability of the latent reservoir for HIV-1 in resting CD4+ T cells. Nat Med 2003, 9:727-728.

114. Hermankova M, Siliciano JD, Zhou Y, Monie D, Chadwick K, Margolick JB, Quinn TC, Siliciano RF: Analysis of human immunodeficiency virus type 1 
gene expression in latently infected resting CD4+ T lymphocytes in vivo. J Virol 2003, 77:7383-7392.

115. Lassen KG, Bailey JR, Siliciano RF: Analysis of human immunodeficiency virus type 1 transcriptional elongation in resting CD4+ T cells in vivo. J Virol 2004, 78:9105-9114.

116. Saleh S, Wightman F, Ramanayake S, Alexander M, Kumar N, Khoury G, Pereira C, Purcell D, Cameron PU, Lewin SR: Expression and reactivation of HIV in a chemokine induced model of HIV latency in primary resting CD4+ T cells. Retrovirology 2011, 8:80.

117. Chun TW, Nickle DC, Justement JS, Large D, Semerjian A, Curlin ME, O'Shea MA, Hallahan CW, Daucher M, Ward DJ, et al: HIV-infected individuals receiving effective antiviral therapy for extended periods of time continually replenish their viral reservoir. J Clin Invest 2005, 115:3250-3255.

118. Pace MJ, Graf EH, Agosto LM, Mexas AM, Male F, Brady T, Bushman FD, O'Doherty U: Directly Infected Resting CD4+T Cells Can Produce HIV Gag without Spreading Infection in a Model of HIV Latency. PLOS Pathog 2012, 8:e1002818.

119. Van Gulck E, Bracke L, Heyndrickx L, Coppens S, Atkinson D, Merlin C, Pasternak A, Florence E, Vanham G: Immune and viral correlates of "secondary viral control" after treatment interruption in chronically HIV-1 infected patients. PLoS One 2012, 7:e37792

120. Graf EH, Mexas AM, Yu JJ, Shaheen F, Liszewski MK, Di MM, Migueles SA, Connors M, O'Doherty U: Elite suppressors harbor low levels of integrated HIV DNA and high levels of 2-LTR circular HIV DNA compared to HIV+ patients on and off HAART. PLOS Pathog 2011, 7:e1001300

121. Blankson JN, Bailey JR, Thayil S, Yang HC, Lassen K, Lai J, Gandhi SK, Siliciano JD, Williams TM, Siliciano RF: Isolation and characterization of replicationcompetent human immunodeficiency virus type 1 from a subset of elite suppressors. J Virol 2007, 81:2508-2518.

122. Strain MC, Little SJ, Daar ES, Havlir DV, Gunthard HF, Lam RY, Daly OA, Nguyen J, Ignacio CC, Spina CA, et al: Effect of treatment, during primary infection, on establishment and clearance of cellular reservoirs of HIV-1. $J$ Infect Dis 2005, 191:1410-1418.

123. Deeks SG: HIV infection, inflammation, immunosenescence, and aging. Annu Rev Med 2011, 62:141-155.

124. van Sighem A, Danner S, Ghani AC, Gras L, Anderson RM, de Wolf F: Mortality in patients with successful initial response to highly active antiretroviral therapy is still higher than in non-HIV-infected individuals. J Acquir Immune Defic Syndr 2005, 40:212-218.

125. Lohse N, Hansen AB, Pedersen G, Kronborg G, Gerstoft J, Sorensen HT, Vaeth M, Obel N: Survival of persons with and without HIV infection in Denmark, 1995-2005. Ann Intern Med 2007, 146:87-95.

126. The Antiretroviral Therapy Cohort Collaboration: Life expectancy of individuals on combination antiretroviral therapy in high-income countries: a collaborative analysis of 14 cohort studies. Lancet 2008, 372:293-299.

127. Soares RS, Tendeiro R, Foxall RB, Baptista AP, Cavaleiro R, Gomes P, Camacho R, Valadas E, Doroana M, Lucas M, et al: Cell-associated viral burden provides evidence of ongoing viral replication in aviremic HIV-2 -infected patients. J Virol 2011, 85:2429-2438.

128. Hunt PW, Hatano H, Sinclair E, Lee TH, Busch MP, Martin JN, McCune JM, Deeks SG: HIV-specific CD4+ T cells may contribute to viral persistence in HIV controllers. Clin Infect Dis 2011, 52:681-687.

129. Hatano $H$, Jain V, Hunt PW, Lee TH, Sinclair E, Do TD, Hoh R, Martin JN, McCune JM, Hecht F, et al: Cell-Based Measures of Viral Persistence Are Associated With Immune Activation and Programmed Cell Death Protein 1 (PD-1)-Expressing CD4+ T cells. J Infect Dis 2012 [Epub ahead of print].

130. Shen L, Siliciano RF: Viral reservoirs, residual viremia, and the potential of highly active antiretroviral therapy to eradicate HIV infection. J Allergy Clin Immunol 2008, 122:22-28.

131. Maldarelli F: Targeting viral reservoirs: ability of antiretroviral therapy to stop viral replication. Curr Opin HIV AIDS 2011, 6:49-56

132. Joos B, Fischer M, Kuster H, Pillai SK, Wong JK, Boni J, Hirschel B, Weber R, Trkola A, Gunthard HF: HIV rebounds from latently infected cells, rather than from continuing low-level replication. Proc Natl Acad Sci U S A 2008 , 105:16725-16730

133. Ramratnam B, Mittler JE, Zhang L, Boden D, Hurley A, Fang F, Macken CA, Perelson AS, Markowitz M, Ho DD: The decay of the latent reservoir of replication-competent HIV-1 is inversely correlated with the extent of residual viral replication during prolonged anti-retroviral therapy. Nat Med 2000, 6:82-85.
134. Zhang L, Ramratnam B, Tenner-Racz K, He Y, Vesanen M, Lewin S, Talal A, Racz P, Perelson AS, Korber BT, et al: Quantifying residual HIV-1 replication in patients receiving combination antiretroviral therapy. $N$ Engl J Med 1999, 340:1605-1613.

135. Frenkel LM, Wang Y, Learn GH, McKernan JL, Ellis GM, Mohan KM, Holte SE, De Vange SM, Pawluk DM, Melvin AJ, et al: Multiple viral genetic analyses detect low-level human immunodeficiency virus type 1 replication during effective highly active antiretroviral therapy. J Virol 2003, 77:5721-5730

136. Deeks SG: HIV: How to escape treatment. Nature 2011, 477:36-37.

137. Bailey JR, Sedaghat AR, Kieffer T, Brennan T, Lee PK, Wind-Rotolo M, Haggerty CM, Kamireddi AR, Liu Y, Lee J, et al: Residual human immunodeficiency virus type 1 viremia in some patients on antiretroviral therapy is dominated by a small number of invariant clones rarely found in circulating CD4+ T cells. J Virol 2006, 80:6441-6457.

138. Evering TH, Mehandru S, Racz P, Tenner-Racz K, Poles MA, Figueroa A, Mohri $H$, Markowitz M: Absence of HIV-1 evolution in the gut-associated lymphoid tissue from patients on combination antiviral therapy initiated during primary infection. PLOS Pathog 2012, 8:e1002506

139. Hermankova M, Ray SC, Ruff C, Powell-Davis M, Ingersoll R, D'Aquila RT, Quinn TC, Siliciano JD, Siliciano RF, Persaud D: HIV-1 drug resistance profiles in children and adults with viral load of $<50$ copies $/ \mathrm{ml}$ receiving combination therapy. JAMA 2001, 286:196-207.

140. Josefsson L, Faria N, Eriksson S, Sinclair E, Shao W, Hunt P, Somsouk M, Deeks SG, Hecht F, Palmer S: In-depth Phylogenetic Analyses of HIV-1 Evolution during Long-term Suppressive Therapy [abstract]. In $20^{\text {th }}$ Conference on Retroviruses and Opportunistic Infections. Atlanta, Georgia; 2013.

141. Vesanen M, Markowitz M, Cao Y, Ho DD, Saksela K: Human immunodeficiency virus type-1 mRNA splicing pattern in infected persons is determined by the proportion of newly infected cells. Virology 1997, 236:104-109.

142. Josefsson L, Eriksson S, Sinclair E, Ho T, Killian M, Epling L, Shao W, Lewis B, Hunt P, Somsouk M, et al: Characterizing Latent HIV Reservoirs [abstract]. Global Antiviral Journal 2011, 7(Suppl 2):11-12.

143. Yukl SA, Shergill AK, McQuaid K, Gianella S, Lampiris H, Hare CB, Pandori M, Sinclair $E$, Gunthard HF, Fischer M, et al: Effect of raltegravir-containing intensification on HIV burden and T-cell activation in multiple gut sites of HIV-positive adults on suppressive antiretroviral therapy. AIDS 2010, 24:2451-2460.

144. Shults K, Flye-Blakemore L, Patterson BK, Elbeik T: Analysis of multiple cell reservoirs expressing unspliced HIV-1 gag-pol mRNA in patients on antiretroviral therapy. Future Virol 2012, 7:819-832.

145. Pasternak AO, de Bruin M, Jurriaans S, Bakker M, Berkhout B, Prins JM, Lukashov W: Modest Nonadherence to Antiretroviral Therapy Promotes Residual HIV-1 Replication in the Absence of Virological Rebound in Plasma. J Infect Dis 2012, 206:1443-1452.

146. Shuter J: Forgiveness of non-adherence to HIV-1 antiretroviral therapy. $J$ Antimicrob Chemother 2008, 61:769-773.

147. Nettles RE, Kieffer TL, Kwon P, Monie D, Han Y, Parsons T, Cofrancesco J Jr, Gallant JE, Quinn TC, Jackson B, et al: Intermittent HIV-1 viremia (Blips) and drug resistance in patients receiving HAART. JAMA 2005, 293:817-829.

148. Sigal A, Kim JT, Balazs AB, Dekel E, Mayo A, Milo R, Baltimore D: Cell-to-cell spread of HIV permits ongoing replication despite antiretroviral therapy. Nature 2011, 477:95-98.

149. Chun TW, Nickle DC, Justement JS, Meyers JH, Roby G, Hallahan CW, Kottilil S, Moir S, Mican JM, Mullins J, et al: Persistence of HIV in gut-associated lymphoid tissue despite long-term antiretroviral therapy. J Infect Dis 2008, 197:714-720.

150. Lafeuillade A, Cheret A, Hittinger G, Bernardini D, Cuquemelle C, Jullian E, Poggi C: Rectal cell-associated HIV-1 RNA: a new marker ready for the clinic. HIV Clin Trials 2009, 10:324-327

151. North TW, Higgins J, Deere JD, Hayes TL, Villalobos A, Adamson L, Shacklett BL, Schinazi RF, Luciw PA: Viral sanctuaries during highly active antiretroviral therapy in a nonhuman primate model for AIDS. J Virol 2010, 84:2913-2922.

152. Yukl SA, Gianella S, Sinclair E, Epling L, Li Q, Duan L, Choi AL, Girling V, Ho T, $L i P$, et al: Differences in HIV burden and immune activation within the gut of HIV-positive patients receiving suppressive antiretroviral therapy. J Infect Dis 2010, 202:1553-1561.

153. Horiike M, Iwami S, Kodama M, Sato A, Watanabe Y, Yasui M, Ishida Y, Kobayashi T, Miura T, Igarashi T: Lymph nodes harbor viral reservoirs that cause rebound of plasma viremia in SIV-infected macaques upon cessation of combined antiretroviral therapy. Virology 2012, 423:107-118. 
154. Cohen J: HIV/AIDS research. Tissue says blood is misleading, confusing HIV cure efforts. Science 2011, 334:1614.

155. Imamichi H, Degray G, Dewar RL, Mannon P, Yao M, Chairez C, Sereti I, Kovacs JA: Lack of compartmentalization of HIV-1 quasispecies between the gut and peripheral blood compartments. J Infect Dis 2011, 204:309-314.

156. McMahon D, Jones J, Wiegand A, Gange SJ, Kearney M, Palmer S, McNulty S, Metcalf JA, Acosta E, Rehm C, et al: Short-course raltegravir intensification does not reduce persistent low-level viremia in patients with HIV-1 suppression during receipt of combination antiretroviral therapy. Clin Infect Dis 2010, 50:912-919.

157. Gandhi RT, Zheng L, Bosch RJ, Chan ES, Margolis DM, Read S, Kallungal B, Palmer $S$, Medvik K, Lederman MM, et al: The effect of raltegravir intensification on low-level residual viremia in HIV-infected patients on antiretroviral therapy: a randomized controlled trial. PLoS Med 2010, 7:e1000321.

158. Buzon MJ, Massanella M, Llibre JM, Esteve A, Dahl V, Puertas MC, Gatell JM, Domingo P, Paredes R, Sharkey M, et al: HIV-1 replication and immune dynamics are affected by raltegravir intensification of HAART-suppressed subjects. Nat Med 2010, 16:460-465.

159. Sharkey ME, Teo I, Greenough T, Sharova N, Luzuriaga K, Sullivan JL, Bucy RP, Kostrikis LG, Haase A, Veryard C, et al: Persistence of episomal HIV-1 infection intermediates in patients on highly active anti-retroviral therapy. Nat Med 2000, 6:76-81.

160. Sharkey M, Triques K, Kuritzkes DR, Stevenson M: In vivo evidence for instability of episomal human immunodeficiency virus type 1 cDNA. Virol 2005, 79:5203-5210.

161. Butler SL, Johnson EP, Bushman FD: Human immunodeficiency virus CDNA metabolism: notable stability of two-long terminal repeat circles. J Virol 2002, 76:3739-3747.

162. Pierson TC, Kieffer TL, Ruff CT, Buck C, Gange SJ, Siliciano RF: Intrinsic stability of episomal circles formed during human immunodeficiency virus type 1 replication. J Virol 2002, 76:4138-4144.

163. Llibre JM, Buzon MJ, Massanella M, Esteve A, Dahl V, Puertas MC, Domingo P, Gatell JM, Larrouse M, Gutierrez M, et al: Treatment intensification with raltegravir in subjects with sustained HIV-1 viraemia suppression: a randomized 48-week study. Antivir Ther 2012, 17:355-364.

164. Besson GJ, McMahon D, Maldarelli F, Mellors JW: Short-course raltegravir intensification does not increase 2 long terminal repeat episomal HIV-1 DNA in patients on effective antiretroviral therapy. Clin Infect Dis 2012, 54:451-453.

165. Gandhi RT, Coombs RW, Chan ES, Bosch RJ, Zheng L, Margolis DM, Read S, Kallungal $B$, Chang M, Goecker EA, et al: No effect of raltegravir intensification on viral replication markers in the blood of HIV-1-infected patients receiving antiretroviral therapy. J Acquir Immune Defic Syndr 2012, 59:229-235.

166. Sharkey M, Babic DZ, Greenough T, Gulick R, Kuritzkes DR, Stevenson M: Episomal viral CDNAs identify a reservoir that fuels viral rebound after treatment interruption and that contributes to treatment failure. PLOS Pathog 2011, 7:e1001303.

167. Archin NM, Liberty AL, Kashuba AD, Choudhary SK, Kuruc JD, Crooks AM, Parker DC, Anderson EM, Kearney MF, Strain MC, et al: Administration of vorinostat disrupts HIV-1 latency in patients on antiretroviral therapy. Nature 2012, 487:482-485.

doi:10.1186/1742-4690-10-4

Cite this article as: Pasternak et al: Cell-associated HIV RNA: a dynamic biomarker of viral persistence. Retrovirology 2013 10:41.

\section{Submit your next manuscript to BioMed Central and take full advantage of:}

- Convenient online submission

- Thorough peer review

- No space constraints or color figure charges

- Immediate publication on acceptance

- Inclusion in PubMed, CAS, Scopus and Google Scholar

- Research which is freely available for redistribution 